\title{
Factors Militating against Implementation of Value Reengineering in the Construction Industry
}

\author{
Winston WM Shakantu ${ }^{1}$, Ibrahim M Jibrin², and Ibrahim Saidu ${ }^{3}$ \\ ${ }^{1}$ Professor, Department of Construction Management, School of the Built Environment, Faculty of Engineering, the Built \\ Environment and Technology, Nelson Mandela University, PO Box 77000, Port Elizabeth, 6031, South Africa. Email: \\ winston.shakantu@mandela.ac.za (corresponding author). \\ ${ }^{2}$ Ph.D. Student, Department of Construction Management, School of the Built Environment, Faculty of Engineering, \\ Built Environment and Technology, Nelson Mandela University, PO Box 77000, Port Elizabeth, 6031, South Africa. E- \\ mail: s221353089@mandela.ac.za \\ ${ }^{3}$ Senior Lecturer, Department of Quantity Surveying, School of Environmental Technology, Federal University of \\ Technology, PMB 65, Minna-Nigeria. Email: saidu.ibr@futminna.edu.ng
}

Project Management

Received December 31, 2020; revised January 22, 2021; July 6, 2021; October 7, 2021; November 16, 2021; December 6, 2021; accepted December 9, 2021

Available online December 27, 2021

\begin{abstract}
Production improvement techniques in use by the Construction Industry (CI) in developing countries like Nigerian are yielding sub-optimal value for customers. This necessitated the investigation of techniques to engender maximum efficiency gains. Hence, continuous improvements on new techniques that will give customer satisfaction are required to be implemented to improve the development of the sector. The adoption of Value Reengineering (VRE) could result in a breakthrough solution in resolving the challenges of customer dissatisfaction in the industry. The subjectivist methodology was utilised to establish critical success factors in thirty-four purposefully sampled building construction operators within Abuja using purposive sampling techniques. The deductive/thematic technique was used to analyse the recorded, transcribed, and interpreted interview data after it had been sorted and coded to develop information about any common pattern among the interviewees' evidence on causes militating against VRE deployment in the CI. The results revealed a significant need for the process to be reengineered through the utility of change enablers and the introduction of assistive technologies. The study further reveals that inadequate employee training to implement VRE, lack of understanding of the implementation requirements, top management commitment, quality standards of contractor's work, and lack of employee consensus to see the implementation through is the key planning, technical and organisational related factors identified. The research concluded that VRE implementation would be achieved if adequate attention is given to the level of awareness of the operator of the technique through training and retraining of operatives in the industry. The study recommends that VRE implementation in all construction projects be encouraged, as it has the potential for the customer to achieve its desired satisfaction on value offering.
\end{abstract}

Keywords: Value Reengineering, construction industry, implementation, technique, and militating factors

Copyright $\odot$ Journal of Engineering, Project, and Production Management (EPPM-Journal).

DOI 10.32738/JEPPM-2022-0008

\section{Introduction}

The construction sector has always been criticised for lack of efficiency in product delivery to meet customer satisfaction in comparison to other sectors (Olanrewaju et al., 2018). The resistance to change by the sector is due to fragmented markets and the processes involved (Arantes et al., 2015). Addressing the sector challenges, the existing characterisation methods need continuous improvements, and new techniques be implemented to improve the development of the sector (Safa et al., 2015). The need for the industry to meet the requirements of value for money to customers, and efficiency in product delivery has prompted the adoption of various value techniques to transform the paradigm of the industry from its traditional practices to the current practices (Arayici et al., 2011). However, these techniques are still proven to display a considerable level of value dissatisfaction (Safa et al., 2015).

Ding et al. (2017) recommend Value Reengineering (VRE) implementation in the construction sector to boost the application techniques. VRE adoption, according to Safa et al. (2015), could result to a break through solution 
for the Construction Industry (CI) in resolving the challenges of customer dissatisfaction. The challenges of the implementation of innovative techniques remain a constraint in both the planning and execution process (Harini and Widyarti, 2018). Yahaya (2020) attributes some of these challenges to lack of awareness, fear of the outcome of the new innovation and developing interest in exploring the benefits of the new technique.

VRE implementation in developing country like Nigeria is given little attention as a result of the low level of awareness amongst the CI operators (Omidi and Khoshtinat, 2016). Jibrin and Shakantu (2021) advocate that creating awareness for VRE application in projects delivery in CI, a set of parameters were identified for construction management and control, and these are driven by the factors militating against VRE implementation, incremental adoption and customer optimal value satisfaction. Hence, the paper aim at examining the challenging factors militating against VRE implementation in the construction sector. The development of new methods like VRE when applied in the industry of the developing nations in areas of the procurement process, supply chain management, concept designed and process management of construction as well as transportation network would create value for the customer (Oke and Ogunsemi, 2011). Consequently, a study conducted by Songer et al. (2000) revealed that under situational VRE, changing work processes and appropriate cultural environment can result in significant schedule reduction by $35 \%$ with no increase in project cost. This however was demonstrated by the model adapted from Kassa (2016) in Fig. 1. Both developed and developing nations of the world have placed an emphasis on growing demand on increasing efficiency, effectiveness and value for money (Olawumi, Akinrata, and Arijeloye, 2016). The construction sector can then become proactive in operation by adopting the VRE process to achieve remarkable improvement in the sector performance of their projects (Eke \& Adaku, 2014). The CI experts have the duty to create new methods that will meet the demands in terms of quality and function, waste minimisation, reduce time and cost of the product to the customers (Smyth, Lecoeuvre and Vaesken, 2018).

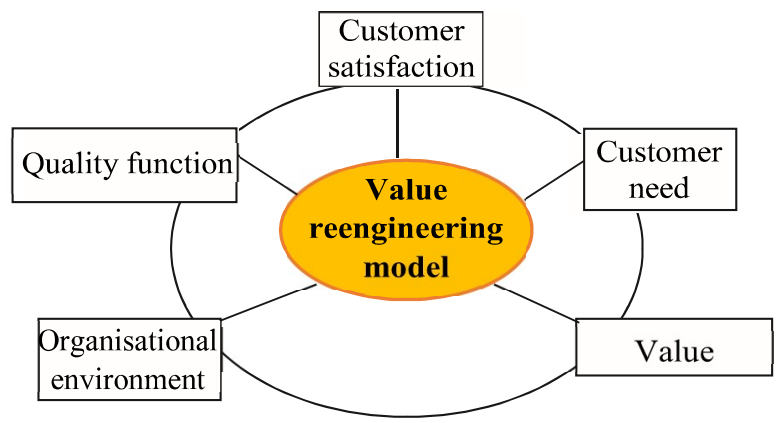

Fig. 1. VRE model (adapted from Kassa, 2016)

Senay and Niyazi (2013) express that VRE implementation in the CI should be applied in developing human capacity, materials resources, specifications of materials, the quality output of the products, design facilities and construction processes. Aghimien and Oke (2015) further, reiterate that implementation of VRE is dynamic in various forms in the construction sector. Chih et al. (2019) posit that VRE implementation in the construction sector could yield a better value when construction is approached in a manner that incorporates benefits of cost reductions, time savings, waste minimization, quality improvements, and isolation of design deficiencies.

\section{Literature Review}

2.1. Concept of VRE Implementation in the Construction Industry

Value reengineering concept is defined as meeting customer satisfaction by achieving the value of the product through the fundamental rethink and radical redesign of the value processes to achieve dramatic improvement in critical contemporary measures of performance such as cost, quality, service and speed.

The concept traces its root back to management theories developed in the early nineteenth (19th) century (Holstrom et al., 1999; Ekanayake and Sandanayake, 2017). The purpose of reengineering is to "make all the processes the best-in-class" (Adeyemi and Aremu, 2008). Mao and Zhang (2008) emphasis that the VRE implementation concept has been applied in many industries as well as manufacturing to redesign the work process in achieving customer value for their product. Puruhita (2018) stress that implementation of the VRE concept has been introduced into the CI with varying levels of success for different projects. Soares (2013) expressed that the concepts are tested in new projects that force CI to shift its tradition into project integration. According to Manuel and Garcia (2012), Soares (2012), and Teicholz (2013), three concepts drive VRE implementation in CI from its tradition into project integration in the management process.

\subsubsection{Design-built concept}

The design-build concept brings back the concept of the Master Builder into play; this brings back integration in the construction process, reduction in costs, increase in collaboration, less waste, and trust (Soares, 2012a; Manuel and Garcia, 2012). Soares (2012b) added that benefits identified by contractors using the design-build concept are quality, time savings, reduced administrative burden, early knowledge of construction costs and improved risk management.

\subsubsection{Building Information Modelling (BIM) concept}

Building information modelling is a collection of tools, processes, and cultural mindsets (Teicholz, 2013). This concept provides automated quantity takeoffs with material cost and labour estimates. Alumbugu, Shakantu and Tsado (2020) reiterate that efficient outbound logistics channels for construction materials management is critical for customer satisfaction in achieving VRE for the CI.

\subsubsection{Lean concept}

The concept of lean gives room for integration in which all work and actions are in perfect symbiosis, that generates clear communication, integrated teams, and contributions of knowledge that must be adjusted too, in order to survive economically (Soares, 2013). The lean concept, according to Miller (2009) is a tool to eliminate waste and increase 
value. Saidu and Shakantu (2017) believed that rework is the major source of waste and can be accounted for up to $10 \%$ of the cost of a conventional project.

\subsection{Factors Affecting VRE Implementation in the Construction Industry}

\subsubsection{Planning factors}

Planning is required in making large scale VRE implementation technique a success (Hussain et al., 2014). More than $70 \%$ of VRE implementations fail due to a lack of proper planning from the inception (Maleki and Beikkhakhian, 2011; Bibi et al., 2014). Guimaraes (1995) observed that planning factors could be viewed in the area of the process, human and operational.

\subsubsection{Technical factors}

The influence of technical factors is jointly considered by Guimaraes (1998), Mohamed and Tucker (1996), Hussain et al. (2014), and Puruhita (2018), as shown in Fig. 2. The symbiotic nature of the construction activities requires the adoption and implementation of VRE in construction projects. Jibrin (2021) stress that the work execution is interrelated with each other, and in other to meet the customer need of value addition, these interrelationships must be closely observed in all the project monitored.

\subsubsection{Organisational factors}

Poor communication between the VRE team and organisation and failure to effectively monitor the progress of the project according to the schedule are the issues faced by the selected organisation in both VRE implementation and post VRE implementation phase (Fasna and Gunatilake, 2019). Puruhita (2018) viewed the most severe environmental factors affecting the adoption and implementation of VRE in an organisation as the creation of an unfriendly company environment and lack of communication between top management and other supporting staff.

Fig. 2 demonstrates the interrelationship existing from the factors of VRE through the application of partnering process of value while considering the past record in terms of time, cost, quality, safety, using the QFD in reviewing the design and proposing alternative integrating work packages to have fewer sub-contracting, thereby applying partnering or strategic alliance concepts. The relationship is further strengthened by defining areas of responsibility risk-reward while integrating design and construction process in applying concurrent engineering principles to enhancing information flow through IT tools in minimising rework and improving material flow.

\section{Research Methodology}

The study adopted a mixed method of qualitative and quantitative to examine the factors militating against the implementation of VRE in the building sector of the CI. The interviews were conducted with 34 key operators in the industry using semi-structured interviews through the qualitative method, and these included 7 Directors, 9 Project managers, 9 Quantity surveyors, and 9 Engineers.

However, according to Leedy and Ormrod (2015), the typical research sample size of the phenomenological study ranges between 5 and 25 participants in unstructured interviews. Therefore, 34 participants are assumed to be adequate.

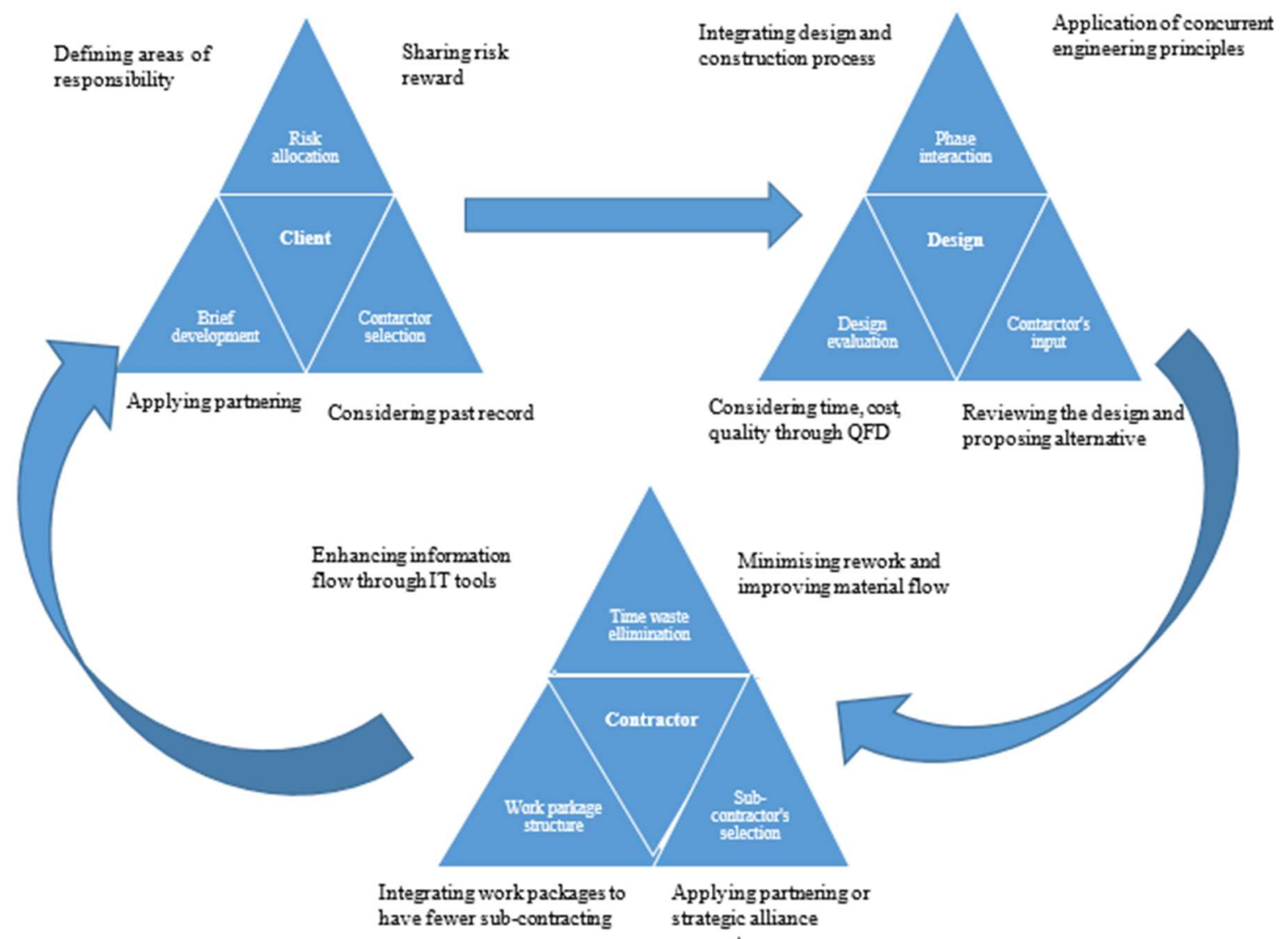

Fig. 2. Mitigating factors affecting VRE implementation Source: adopted from Mohamed and Tucker (1996) 
Based on the nature of this research, the study adopted the phenomenological paradigm as it is the most appropriate approach for the study. Data for this research was collected from the interview in connection with a tickbox questionnaire. An interview guide and a tick-box questionnaire were developed on separate documents. As interviews were conducted with the respondents, the researcher ticked the factors highlighted in the questionnaire, in order to assess the rate of occurrence of these factors. Therefore, the results in the tick-box questionnaire are those presented and analysed in section 4 of this article. The interview guide and the tick-box questionnaire are presented in the appendix for more clarification. Interviews were mostly at the interviewee's offices; and these last from 45 to 75 minutes or more.

Nine (9) different construction firms that have a capital base of about 4.6 million USD (1.8 billion Naira) and above were purposively selected among the firms engaging on both building and civil works. Leedy and Ormrod (2014) maintain that qualitative researchers often employ purposive sampling through which the selection of individuals is made, based on their experiences, in order to yield adequate information about the topic under investigation. However, the rationale behind the selection of purposive sampling technique was employed, to enable the researcher to select participants (operators) from different construction firms based on the perceived experience and survival in business for an investigation that is likely to give the ideal information. The CI domicile in Abuja, north-central Nigeria, is selected because of huge construction going on in the area.

The type of primary data generated in this research was interview recorded by the researcher through unstructured and in-depth interviews with participants. According to Mustafa (2012) collection of primary data can be through personal interviews, telephone interviews, and mailing of questionnaires. However, the secondary data for this study were sourced through published and unpublished books, dissertations and theses, texts, local and international academic journals, articles and conference papers and industrial publications. According to Osuji and Ishola (2013), secondary data are not first-hand information, facts or statistical materials that originated by the researcher.

The interview data were analysed using the thematic/deductive analytical method. It is thematic because data could be presented by transcribing, coding and setting themes from the responses of the interviewees. Hence, for the purpose of this study, the recorded, transcribed and interpreted interview data were analysed by using the deductive approach and the quantitative data was analysed using a descriptive method which included frequencies and percentiles. Data generated in this research were interpreted and presented through descriptive and narrative analysis. Hence, analyses of data are done by altering qualitative data from the interview results obtained into quantitative data. Therefore, implementation of VRE factors is rated, on the basis of cut-off points as highlighted by Saidu (2016) on a five-point Likert scale. The cut-off points, expressed in frequencies are further converted to percentages; consequently, the analyses of the results are expressed in percentage as indicated below, in which the assumption value answer are as follows: $1=$ unimportant, 2
$=$ less important, $3=$ fairly important, $4=$ important and 5 $=$ most important. Militating factors against the implementation of VRE in the building sector of the CI that have a percentage of between 90 to 100 are rated most important; 70 to 89 percent are rated important; 50 to 69 percent are rated fairly important; 30 to 49 percent are rated less important, and 1 to 29 percent are rated unimportant.

\section{Results Analysis}

\subsection{Findings from the Interview}

The section presents the research findings of the interview on factors militating against VRE implementation by the respondent, and this is divided into two parts: respondents profile and interviewees results.

\subsubsection{Respondents profile}

The profile of the respondents that were interviewed during research includes position of the respondents, nature of the work carried out, and years of engagement of the respondents in the organisation.

Table 1. Respondent designation

\begin{tabular}{lcc}
\hline \multicolumn{1}{c}{ Position } & Respondent & Percentage \\
\hline Director & 7 & 20.58 \\
Project & 9 & 26.47 \\
Manager & & \\
Quantity & 9 & 26.47 \\
Surveyor & & \\
Engineer & 9 & 26.47 \\
\hline
\end{tabular}

Table 1 indicates that $20.6 \%$ are in the director's cadre, while $26.5 \%$ were project managers; quantity surveyors; and engineers for the construction firms that were visited.

Table 2. Work classification

\begin{tabular}{lcc}
\hline $\begin{array}{l}\text { Work } \\
\text { Classification }\end{array}$ & $\begin{array}{c}\text { No. of } \\
\text { Respondent } \\
\text { s }\end{array}$ & $\begin{array}{c}\text { Percentage of } \\
\text { Respondents }\end{array}$ \\
\hline Civil Works & 6 & 17.65 \\
Building Works & 10 & 29.41 \\
Both (Building \& & 18 & 52.94 \\
Civil) & & \\
\hline
\end{tabular}

In Table 2, different categories of work been executed by the construction firms visited were classified as $17.7 \%$ for civil engineering works; $29.4 \%$ are into building construction works, and $52.9 \%$ are into building and civil works.

Table 3. Working experience

\begin{tabular}{lcccc}
\hline Years & $0-5$ & $6-10$ & $11-15$ & Above 15 \\
\hline $\begin{array}{l}\text { Number of } \\
\text { Respondents }\end{array}$ & 2 & 4 & 16 & 12 \\
Percentage & 5.88 & 11.76 & 47.06 & 35.29 \\
\hline
\end{tabular}

Table 3 shows the years of working experience of the operators interviewed, and this indicates that $82 \%$ of the construction operators interviewed have been in the field of building construction sector for more than 11 years, only $18 \%$ are in the building sector less than ten years. In view of these, the results show a degree of the high level of reliability. 


\subsubsection{Factors militating against VRE implementation in $\mathrm{CI}$}

VRE in the CI is faced with many factor hindrances to its implementation, leading to customer dissatisfaction. The interviews conducted with building operators on the planning, technical, and organisational related factors are explained as follows.

\subsubsection{Influence of planning factors}

Planning related issues responsible for the implementation of VRE are the principal concern among many construction professionals in the industry. These issues were taken into account by the respondents during the interview and these are planning, human and process operation. In Table 4 it shows that $91.2 \%$ of the operators interviewed believed that inadequate employee training to implement VRE is considered the most important planning factor affecting the process implementation, $85.3 \%$ equally responded that difficulty to match the best technology with the new process is another planning related factor, while $82.4 \%$ of the respondents also believed that workers fear of job loss and lack of understanding the implementation requirements of VRE process with $76.5 \%$ respondents are viewed as the main planning related factor militating against the implementation. The result further revealed that top management commitment is $58.8 \%$, collaborative work environment $55.9 \%$, redesigning processes that are obsolete $55.9 \%$, focusing on new technology instead of the value process $52.9 \%$, change in management system $50.0 \%$, uncertainty of project outcome $50.0 \%$ and anxiety in the workplace $50.0 \%$ are observed to be the fairly important factor in planning, militating against VRE implementation.

Other factors with less impact are forgetting about employee working habits $41.8 \%$, sense of discomfort $44.1 \%$, VRE was much larger than anticipated $35.3 \%$, and lowering the employee morale by $32.4 \%$. However, $29.4 \%$ of the respondents viewed conflicts between traditional performance measures and VRE goals as planning related factors, $26.5 \%$ believe making value mistake under pressure to produce a quick result as a factor in the planning process, $23.5 \%$ considered trying to change too much quickly to be another factor, $20.6 \%$ view Lowering the productivity of the employee and $17.8 \%$ equally view VRE as too disruptive to value operations and are having less Influence in the implementation process.

\subsubsection{Influence of technical factors}

Assessing the impact of technology-related factors on the implementation of VRE in the CI, forty-one parameters are critically examined. From Table 5, important technical factors identified to be militating against the implementation of VRE during the interviews are client incorporation in the design phase so that the incidence of variations and time extension is reduced $88.2 \%$, the quality standards of contractor's work $88.2 \%$ form the important challenge as well, other important factors that are rated by the respondents during the interview are: design parameters $73.5 \%$, involvement of design team and client through partnering integration $70.6 \%$, and partnering in the context of a contractor-sub contractor relationship 70.6\%.

Moreover, factors equally considered fairly important militating against VRE implementation include: continuous growth and acceptance of change $67.7 \%$, creating conditions and opportunities to make organisational change $67.7 \%$, enhancement of contractor's productivity $67.7 \%$, time consuming $67.7 \%$, adoption of design features to site conditions $64.7 \%$, lack of interaction that affect quality and serviceability of design phase $64.7 \%$, encouraging the employees to learn $61.8 \%$, design and manage $61.8 \%$, QFD to facilitate evaluation of proposed design $61.8 \%$, creating the new view of the organisation $58.8 \%$, financial stability of the contractor $58.8 \%$, existing common goal between the design team and client $55.9 \%$, long implementation time that rendered VRE changes obsolete $55.9 \%$, concurrent design/construction that form the client satisfaction $55.9 \%$, client requirement which should be understood during brief development by the designer $50.0 \%$, and simultaneous consideration of conceptual design phase $50 \%$.

Table 4. Planning related factors

\begin{tabular}{clc}
\hline S/no & \multicolumn{1}{c}{ Militating factors } & Percentage \\
\hline 1 & Redesigning the processes that are obsolete & 55.9 \\
2 & Difficulty in matching the best technology with the new process & 85.3 \\
3 & Focusing on the new technology instead of achieving value process & 52.9 \\
4 & Forgetting the employee working habits to achieve new process & 41.8 \\
5 & Lack of understanding the implementation requirements & 76.5 \\
6 & Conflict between traditional performance measures and VRE goals & 29.4 \\
7 & Inadequate employee training to implement VRE & 91.2 \\
8 & Workers' fear of job loss & 82.4 \\
9 & Uncertainty of project outcome & 50.0 \\
10 & Sense of discomfort & 44.1 \\
11 & Anxiety in the workplace & 50.0 \\
12 & Collaborative work environment & 55.9 \\
13 & Top management commitment & 58.8 \\
14 & Changes in the management system & 50.0 \\
15 & VRE was much larger than anticipated & 35.3 \\
16 & VRE was too disruptive to value operations & 17.8 \\
17 & Trying to change too much too quickly & 23.5 \\
18 & Making value mistakes under pressure to produce quick result & 26.5 \\
19 & Lower employee productivity & 20.6 \\
20 & Lower employee morale & 32.4 \\
\hline
\end{tabular}


Table 5. Technical related factors

\begin{tabular}{|c|c|c|}
\hline S/no & Militating factors & Percentage \\
\hline 1 & Creating the new view for the organization & 58.8 \\
\hline 2 & Creating a shared process vision & 17.8 \\
\hline 3 & Management styles and leadership & 20.6 \\
\hline 4 & Encourage employees to learn & 61.8 \\
\hline 5 & Continuous growth and acceptance of change & 67.7 \\
\hline 6 & Create conditions and opportunities to make organizational change & 67.7 \\
\hline 7 & $\begin{array}{l}\text { Client incorporation in the design phase so that the incidence of variations and time } \\
\text { extensions are reduced. }\end{array}$ & 88.2 \\
\hline 8 & Client requirement should be understood during Brief development by the designer & 50.0 \\
\hline 9 & Involvement of Design team and client through partnering integration & 70.6 \\
\hline 10 & Past performance of the contractor & 41.8 \\
\hline 11 & Quality standards of contractor's work & 88.2 \\
\hline 12 & Financial stability or status of the contractor & 58.8 \\
\hline 13 & Lump sum contract & 20.6 \\
\hline 14 & Design and construct & 41.8 \\
\hline 15 & Turn- key contract & 2.9 \\
\hline 16 & Design and manage & 61.8 \\
\hline 17 & Risk issue relative to project participant & 35.3 \\
\hline 18 & Risk strategy adopted by client & 44.1 \\
\hline 19 & Existing common goal between the design team and client & 55.9 \\
\hline 20 & Difficulties in design evaluation & 20.6 \\
\hline 21 & Any formal approach to design evaluation & 17.8 \\
\hline 22 & Core design parameters like time, cost, and quality & 73.5 \\
\hline 23 & Quality Function Development (QFD) facilitate evaluation of proposed design & 61.8 \\
\hline 24 & Allow review design by contractor to eliminate problem & 41.8 \\
\hline 25 & Ease of construction & 47.1 \\
\hline 26 & Adoption of design features to site conditions & 64.7 \\
\hline 27 & Enhancement of contractor's productivity & 67.7 \\
\hline 28 & Ability to substitute materials, components and systems & 44.1 \\
\hline 29 & Lack of interaction may affect quality and serviceability of design phase & 64.7 \\
\hline 30 & Simultaneous consideration of conceptual design phase & 50.0 \\
\hline 31 & Concurrent design/construction are client satisfaction & 55.9 \\
\hline 32 & Work packages by different contractors & 41.8 \\
\hline 33 & Partnering in the context of a contractor-sub contractor relationship & 70.6 \\
\hline 34 & Top management reluctance to commit funds for VRE & 41.8 \\
\hline 35 & Time consuming & 67.7 \\
\hline 36 & Long implementation time rendered VRE changes obsolete & 55.9 \\
\hline 37 & Rework time- variation \& error & 35.3 \\
\hline 38 & Material flow & 35.3 \\
\hline 39 & Mode of information systems to support value reengineering infrastructure & 32.4 \\
\hline 40 & Insufficient information & 20.6 \\
\hline 41 & $\begin{array}{l}\text { Lack of communication between CEO/top management and Inspection officers/supervisory } \\
\text { manager }\end{array}$ & 23.5 \\
\hline
\end{tabular}

Furthermore, other less or unimportant militating factors against the implementation of VRE techniques are: ease of construction $47.1 \%$, risk strategy adopted by client $44.1 \%$, ability to substitute materials $44.1 \%$, past performance of the contractor $41.8 \%$, top management reluctance to commit funds for VRE implementation $41.8 \%$, design and construct $41.8 \%$, allow review design by the contractor to eliminate problem $41.8 \%$, work packages by different contractors $41.8 \%$, risk issue relative to project participant $35.3 \%$, rework time-variation and error $35.3 \%$, material flow $35.3 \%$ and mode of information systems to support value reengineering infrastructure $32.4 \%$. Others are lack of communication between $\mathrm{CEO} /$ top management and inspection officers/supervisory manager $23.5 \%$, insufficient information $20.6 \%$, lumpsum contract $20.6 \%$, difficulties in design evaluation $20.6 \%$, management style and leadership 20.6\%, any formal approach to design evaluation $17.8 \%$, creating a share process vision $17.8 \%$, and Turn-key contract $2.9 \%$.

\subsubsection{Influence of organisational factors}

Effects of organisational factors militating against the implementation of VRE in the CI are discussed under cultural and environmental issues with thirteen parameters. Table 6 present the result of the interview conducted on cultural and environmental challenges that constitute major important organisational factors militating against VRE implementation in the building sector of the construction industry. $94.1 \%$ considered having the capacity and experience for change is a key important cultural factor militating against the implementation of VRE in the sector. 
Table 6. Organisational related factors

\begin{tabular}{|c|c|c|}
\hline S/no & Militating factors & Percentage \\
\hline 1 & Subjective involvement with the work completion & 67.7 \\
\hline 2 & Stability and behavior of staff originating from fundamental values & 85.3 \\
\hline 3 & Mindful of their mistakes by the customers & 58.8 \\
\hline 4 & Having the capacity and experience for change & 94.1 \\
\hline 5 & Continually improving the organization's ability to value customers & 79.4 \\
\hline 6 & Company environment not conducive to reengineering & 38.2 \\
\hline 7 & VRE created an unfriendly company environment & 23.5 \\
\hline 8 & Downsizing but keeping the old organization structure & 26.5 \\
\hline 9 & Difficult implementation due to subunits communication barriers & 17.8 \\
\hline 10 & Lack of leadership to face confrontations and major business risk & 73.5 \\
\hline 11 & Lack of senior management enthusiasm & 38.2 \\
\hline 12 & Lack of employee consensus to see it through & 85.3 \\
\hline 13 & Lack of management determination to stay on course as problems show & 44.1 \\
\hline
\end{tabular}

Continually improving the organisation's ability to value customers are considered with $79.4 \%$, lack of employee's consensus to see VRE implementation through is the culture of the environmental factors with $85.3 \%$ respondents view, and $73.5 \%$ viewed lack of leadership to face confrontations and major business risk as another environmental key factors affecting VRE implementation process. Subsequently, subjective involvement with the work completion of $67.7 \%$ and mindful of the mistake by the customers of $58.8 \%$ are unanimously view fairly important factors affecting the implementation of VRE in the building construction sector. However, $44.1 \%$ believe that lack of management determination to stay on course as problem shows, $38.2 \%$ view company environment not conducive to reengineering and lack of senior management enthusiasm of $38.2 \%$ are considered less important factors responsible for non-VRE implementation, and other unimportant factors observed hindrances to the implementation of VRE are downsizing but keeping the old organisational structure with $26.5 \%$, creation of VRE unfriendly environment for the company to operate is $23.5 \%$, while difficulty to implement due to subunits barriers of the communication originating from the industry are $17.8 \%$, these challenging issues have no doubt retired the progress and advancement of building construction sector is facing the trend of the globally competitive market as a result of new techniques that offers the customers quality products with satisfied value offering within the shortest possible time with less cost not been adopted for the growth of the industry.

\section{Discussion}

This research seeks to identify the factors militating against the implementation of VRE in the CI. It was found that the majority of the factors investigated in Tables 4,5 , and 6 fundamentally influence the implementation of VRE in the CI. Therefore, identifying how these factors influence the implementation of VRE by the CI operators resolved the challenges that are confronted by the operators in the industry. However, the most important planning factors affecting the implementation of VRE in the research are the inadequate employee training to implement the process; difficulty in matching the best technology with the new process; Workers' fear of job loss; and lack of understanding of the implementation requirement. Therefore, changing the fortune of the CI can be surmounted by the workers having no fear of their job being lost as a result of the new technique, due to the inadequate training received by the operators and also understanding the implementation requirement that would match the best technology with the new process innovation, these, however, is supported by Puruhita (2018) and Fasna and Gunatilake (2019). Consequently, it was found that technical related factors affecting the implementation in the CI are: lack of client involvement in the design phase that results in incidence of variations and time extensions; quality standards of contractor's work; and involvement of design team and client through partnering integration; and partnering in the context of a contractor-sub contractor relationship are also necessary. Findings reveal in the study shows that the influence of technical factors affecting the VRE implementation process in the CI as investigated by these researchers Guimaraes (1995); Mohamed and Tucker (1996); and Hussain et al. (2014) can be annulled by the strategic involvements that can be established based on the underpinning instruments mined through design frameworks. These would go a long way in achieving a significant success of implementation in the process with a limited failure rate when the designed framework is critically followed. Furthermore, organisational related factors militating against VRE implementation in the CI identified in the study indicates that having the capacity and experience for change is the most influencing factor, similarly, lack of employee consensus to see the reengineering through; lack of leadership to face confrontations and major business risk; stability and behavior of staff originating from the fundamental values as well as continually improving the organisation's ability to value customer's needs; and lack of employee consensus to see VRE through, were negated by Soares (2013) as the important factors originating from the organisational factors affecting the implementation of VRE process in the CI.

Hence, VRE implementation by developing countries like Nigeria, Brazil, South Africa, Indonesia and Malaysia, among other nations, would derive the benefits of cost reduction, waste minimisation and completion of the project on schedule through the dramatic improvement by 
adopting radical redesign performance process in other to achieve customer value for the projects. Given the nature of VRE in creating fundamental changes in all aspects of strategy, processes, technologies, and human resources, it can be said that this process has a high level of risk and usually, about $70 \%$ of reengineering projects fail in action (Nauman, 2013). Omidi and Khoshtinat (2016), however, argue that despite the significant growth of value process reengineering concepts, all the organisations that have begun their implementation have not achieved a scientific model that can help them achieve their desired results.

To achieve success in VRE implementation in construction sector, employees should be provided with the essential information that can help the sector to successfully reengineer their value operations like the way it is done in industries, banking, breweries, government organisations, airways, ICT and manufacturing sectors in places like USA, UK, Iran, Malaysia, Kenya, Ghana and Nigeria.

\section{Conclusions}

The global spread of the VRE technique is limited in most developing countries due to the awareness level of the technique. Based on the findings, it can be concluded that VRE implementation in the CI can be achieved if adequate attention is pay on the awareness level, through training of the competent professional/operatives in the industry by attending seminars, workshops and conferences in other to avail them on the new technologies/techniques that are traded in the global market, and this will be an opportunity for global market competitiveness for the nation's CI. The study recommends that VRE implementation in all construction projects should be enforced, as it has the potential for the customer to achieve its desired satisfaction on value offering.

The study is limited to the factors militating against the implementation of VRE in the CI, focusing on both private and public construction companies executing building and civil engineering work in Abuja. Other limitation of the study was the conduct of using a tick box questionnaire with the interview guide that is ticked by the researcher in order to assess the rate of occurrence of the factors. Furtherance to the limitation of the study is the geographical nature of the study area; since this study covered only one out of the six geopolitical zones of the country, other zones should be studied and compare the results.

\section{References}

Adeyemi, S. and Aremu, M. A. (2008). Impact assessment of business process reengineering on organisational performance. European Journal of Social Sciences, $7(1), 115-125$.

Aghimien, D. O. and Oke, A. E. (2015). Application of value management to selected construction projects in Nigeria. Developing Country Studies, 5(17), 5-14.

Alumbugu, P. O., Shakantu, W. W. M., and Tsado, A. J. (2020). Analysis of outbound logistics channels for construction material. Journal of Engineering, Project, and Production Management, 10(1), 19-26.

Arantes, A., Ferreira, L. M. D. F., and Costa, A. A. (2015). Is the construction industry aware of supply chain management? The Portuguese contractors perspective. Supply Chain Management: An International Journal, 20(4), 404-414. https://doi.org/10.1108/SCM-06-2014-0207

Arayici, Y., Coates, P., Koskela, L., Kagioglou, M., Usher, C., and O'Reilly, K. (2011). BIM adoption and implementation for architectural practices. Structural Survey, 29(1), https://doi.org/10.1108/02630801111118377

Bibi, S. and Hassan, M. S. (2014). Factors affecting business process reengineering in ERP implementation: A literature review. International Review of Basic and Applied Sciences, 2(8), 113-119. www.irbas.academyirmbr.com

Chih, Y., Zwikael, O., and Restubog, L. S. D. (2019). Enhancing value co-creation in professional service projects: The roles of professionals, clients and their effective interactions. International Journal of Project Management, 37(5), 599-615. https://doi.org/10.1016/j.ijproman.2019.04.001

Ding, Z., Jiang, S., Ng, F., and Zhu, M. (2017). A new TRIZ-based patent knowledge management system for construction technology innovation. Journal of Engineering, Design and Technology, 15(4), 456-470. https://doi.org/10.1108/JEDT-03-2016-0017

Ekanayake, E. M. A. C. and Sandanayake, Y. G. (2017). LiVE approach: Lean integrated Value Engineering for construction industry. Built Environment Project and Asset Management, 7(5), 518-533. https://doi.org/10.1108/BEPAM-11-2016-0071

Eke, G. N. and Adaku, N. A. (2014). Business process reengineering in organizational performance in nigerian banking. Academic Journal of Interdisciplinary Studies, 3(5), 113-124. https://doi.org/10.5901/ajis.2014.v3n5p113

Fasna, M. F. F. and Gunatilake, S. (2019). Issues in Implementing Business Process Reengineering (BPR) Projects. Proceedings of the International Conference on Industrial Engineering and Operations Management Bangkok, Thailand, March 5-7, 2019, 2567-2576.

Guimaraes, T. (1995). Outcome assessment of business process reengineering (pp. 247-261). Elsevier Science Inc.

Guimaraes, T. (1998). Important factors for BPR success in manufacturing firms. Gestão \& Produção, 5(1), 117. $530 \times 1998000100001$

Harini, M. W. and Widyarti, M. (2018). Implementation of value engineering for construction efficiency. Asian Journal of Applied Sciences, 06(02), 71-77.

Holstrom, J., Hoover, W. E., Eloranta, E., and Vasara, A. (1999). Using value reengineering to implement breakthrough solutions for customers. The International Journal of Logistics Management, 10(2), $1-14$.

Hussain, M., Saleh, M., Akbar, S., and Jan, Z. (2014). Factors affecting readiness for business process reengineering-developing and proposing a conceptual model. European Journal of Business and Management, 6(1), 55-60.

Jibrin, I. M. (2021). Value Reengineering in the Nigerian Construction Industry, Unpublished $\mathrm{PhD}$ thesis Submitted to the Department of Construction Management, Nelson Mandela University, Port Elizabeth, South Africa.

Jibrin, I. and Shakantu, W. (2021). Implementation of the value re-engineering concept in the Nigerian 
construction industry: Exploratory study, Acta Structilia. 28(1), 68-90.

Kassa, A. O. (2016). Value Analysis and Engineering Reengineered. CRC Press is an imprint of the Taylor \& Francis Group.

Leedy, P. and Ormrod, J. E. (2014). Practical Research: Planning and Design ((10th ed.). Pearson Education Limited.

Maleki, T. and Beikkhakhian, Y. (2011). Business process reengineering implementation: an investigation of critical success factors. In International Conference on Information and Finance, IPEDR, 21, 17-21.

Manuel, A. and Garcia, P. E. (2012). CII Best Practices Guide. In Construction Industry Institute Implementation Strategy Committe (Version 4.). Construction Industry Institute. https://www.construction-

institute.org/Store/CII/Publication_Pages/bp.cfm?secti on $=$ orders

Mao, X. and Zhang, X. (2008). Construction process reengineering by integrating lean principles and computer simulation techniques. Journal of Construction Engineering and Management, 134(5), 371-381. 93642008134

Miller, R. (2009). The commercial Real Estate RevolutionNine transforming Keys to lowering coasts, cutting waste, and Driving change in a broken Industry. John Wiley \& Sons, Inc.

Mohamed, S. and Tucker, S. (1996). Options for applying BPR in the Australian construction industry. International Journal of Project Management, 14(6), $379-385$.

Mustafa, A. (2012). Research Methodology. (Second ed.). AITBS Publishers.

Nauman, H. M. (2013). Understanding Critical Success and Failure Factors of Business Process Reengineering, international review of management and business research.

Oke, A. E. and Ogunsemi, D. R. (2011). Value management in the Nigerian construction industry: Militating factors and perceived benefits. Proceeding of the Second International Conference on Advances in Engineering and Technology. Faculty of Technology, Mak, 353-359.

Olanrewaju, O. I., Idiake, J. E., Oyewobi, L. O., and Akanmu, W. P. (2018). Global economic recession: causes and effects on Nigeria building construction industry. Journal of Surveying, Construction and Property (JSCP), 9(1), 1-18. https://doi.org/10.22452/jscp.vo19no1.2

Olawumi, T. O., Akinrata, E. B., and Arijeloye, B. T. (2016). Value management - creating functional value for construction project : An exploratory study. World Scientific News 5 Completion, 4, 40-59.

Omidi, A. and Khoshtinat, B. (2016). Factors affecting the implementation of business process reengineering: taking into account the moderating role of organizational culture (Case Study: Iran Air). Procedia Economics and Finance, 36(16), 425-432. https://doi.org/10.1016/S2212-5671(16)30058-2

Osuji, I., and Ishola, T. O. (2013). Business research methodology. National Open Univercity of Nigeria.

Puruhita, H. W. (2018). The readiness of building construction companies to implement re-engineering in Surakarta region. AIP Conference Proceedings, June, 1-8. https://doi.org/10.1063/1.5042957
Safa, M., Sabet, A., MacGillivray, S., Davidson, M., Kaczmarczyk, K., Haas, C. T., Gibson, G. E., and Rayside, D. (2015). Classification of Construction Projects. World Academy of Science, Engineering and Technology. International Journal of Civil, Environmental, Structural, Construction and Architectural Engineering, 9(6), 625-633.

Saidu, I. (2016). Management of material waste and cost overrun in the Nigerian construction industry Ibrahim saidu 2016. Nelson Mandela University, Port Elizabeth, South Africa.

Saidu, I. and Shakantu, W. (2017). A post-contract project analysis of material waste and cost overrun on construction sites in Abuja, Nigeria. Acta Structilia, 24(2), 77-105.

Senay, A. and Niyazi, G. (2013). Application of value engineering in construction projects. Journal of Traffic and Transportation Engineering, 1(1), 39-48.

Smyth, H., Lecoeuvre, L., and Vaesken, P. (2018). Cocreation of value and the project context: towards application on the case of Hinkley point $\mathrm{C}$ nuclear Power Station. International Journal Project Management, 36(1), 170-183.

Soares, R. (2012a). Change orders ordeal: The output of project disintegration. International Journal of Business, Humanities and Technology, 2(1).

Soares, R. (2012b). Trust - The missing link in construction. International Journal of Business and Social Science, 3(23).

Soares, R. (2013). Reengineering management of construction projects. International Journal of Business and Social Science, 4(7), 1-6.

Songer, A. D., Diekmann, J., Hendrickson, W., A., and Flushing, D. (2000). Situational reengineering: Case study analysis,. Journal of Construction Engineering and Management, 126(3), 158-190.

Teicholz, P. (2013). Labor-productivity declines in the construction industry: causes and remedies. AECbytes Viewpoint.

Yahaya, I. (2020). Utilization of technology to improve construction logistics in Nigerian. Unpublished $\mathrm{PhD}$ thesis Submitted to the Department of Construction Management, Nelson Mandela University, Port Elizabeth, South Africa.

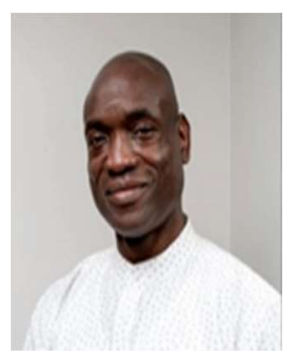

Winston Moonga Shakantu is a holder of Bachelor of Science Building, Master of Science Construction Management (Reading), and Doctor of Philosophy Construction Management (Glasgow Caledonian). $\mathrm{He}$ is also a member of Chartered Institute of Building (MCIOB-UK) and Professional Construction Manager (PrCM-RSA). Winston Shakantu is a Professor of Construction Management at Nelson Mandela University in South Africa. His research interests are in Construction Automation and Robotics, Innovative Technology, Construction Logistics, and Supply Chain Optimisation. 
96 Winston, W. M., Jibrin, I. M., and Saidu, I.

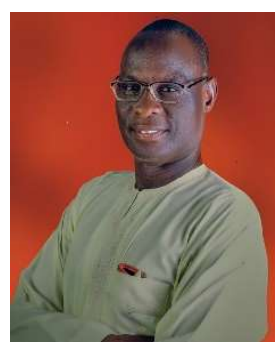

Ibrahim Alhaji Mohammed Jibrin obtained Bachelor of Technology (Building) and Post Graduate Diploma in Environmental Management both from Federal University Technology (Minna). He further proceeded to have Master of Science in Construction Management from University of Jos (Jos), in Nigeria. Ibrahim Alhaji Mohammed Jibrin is a Ph.D. student at the Department of Construction Management, School of the Built Environment, Faculty of Engineering, the Built Environment and Technology, Nelson Mandela University, Port Elizabeth, (South Africa). He currently worked with the Federal Polytechnic Bida, Niger StateNigeria. He is a holder of Member Nigerian Institute of Building (MNIOB), Member Council of Registered Builders of Nigeria (CORBON), with research interests in Value Re engineering, and Health and Safety.

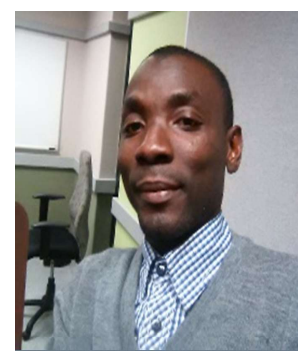

Saidu Ibrahm is a holder of Bachelor of Technology Quantity Surveying Federal University of Technology (Minna), Master of Science Construction Management, University of Jos, (Nigeria), and Doctor of Philosophy Construction Management (NMMU, South Africa). He is a member of the Nigerian Institute of Quantity Surveyor (MNIQS) and Register Quantity Surveyor (RQS). Saidu Ibrahim is a Senior Lecturer at the Federal University of Technology, Minna, Nigeria. His research interests are in Construction Waste Management, Construction Cost Management, and Construction Procurement. 
Result of tick box used by the interviewer in connection with interview guide SECTION A: FACTORS MILITATING AGAINST VRE IMPLEMENTATION IN THE CI

\begin{tabular}{|c|c|c|c|c|c|c|c|c|c|c|c|c|c|c|c|c|c|c|c|c|c|c|c|c|c|c|c|c|c|c|c|c|c|}
\hline$\sum_{a}^{\infty}$ & Militating factors against value reengineering implementation & - & น & ما & $\Delta$ & $\pi$ & $a$ & +2 & $\infty$ & 0 & $=$ & $=$ & t5 & F & 元 & 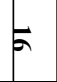 & 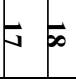 & 6 & $\approx$ & $=$ & N & $\tilde{E}$ & $\tilde{n}$ & $\approx$ & $\sqrt{4}$ & 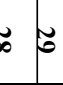 & 急 & $\omega$ & e t & 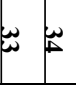 & & Total & $\%$ \\
\hline 1a & Factors related to process planning & $=$ & $\approx$ & F & $E$ & $\nabla_{n}$ & 2 & 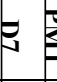 & & & & 永 & $\frac{1}{2}$ & $\frac{3}{4}$ & $\sum_{\infty}^{\infty}$ & $\frac{1}{6}$ & $p_{0}$ & 常 & F & $\beta_{1}$ & $\sum_{2}^{2}$ & $b_{0}^{\infty}$ & b & 2 & $x^{2}$ & 胥 & 界 & 2 & $\mathrm{f}^{2}$ & $\$$ & & Codes & \\
\hline 1.1 & Redesigning processes that are obsolete & & $\mathrm{x}$ & & $\mathrm{x}$ & & & & $\mathrm{x}$ & $\mathrm{x}$ & $\mathrm{x}$ & $\mathrm{x}$ & & $x \quad x$ & \begin{tabular}{c|c}
$x$ & $x$ \\
\end{tabular} & $x$ & $\mathrm{x}$ & $\mathrm{x}$ & $\mathrm{x}$ & & $\mathrm{x}$ & $\mathrm{x}$ & & $\mathrm{x}$ & & $\mathrm{x}$ & $x$ & & $\mathrm{x}$ & & & 19 & 56 \\
\hline 1.2 & Difficulty to match best technology with the new process & $\mathrm{x}$ & $\mathrm{x}$ & & $\mathrm{x}$ & $\mathrm{x}$ & $\mathrm{x}$ & $\mathrm{x}$ & $\mathrm{x}$ & $\mathrm{x}$ & $\mathrm{x}$ & $\mathrm{x}$ & \begin{tabular}{l|l}
$\mathrm{x}$ & $\mathrm{x}$ \\
\end{tabular} & $\mathrm{x}$ & $\mathrm{x}$ & $\mathrm{x}$ & & $\mathrm{x} \quad \mathrm{x}$ & $\mathrm{x}$ & $\mathrm{x}$ & $\mathrm{x}$ & $\mathrm{x}$ & $\mathrm{x}$ & $\mathrm{x}$ & $\mathrm{x}$ & $\mathrm{x}$ & \begin{tabular}{l|l}
$\mathrm{x}$ & $\mathrm{x}$ \\
\end{tabular} & $\mathrm{x} x \mathrm{x}$ & $\mathrm{x}$ & \begin{tabular}{|l|l|l}
$\mathrm{x}$ & $\mathrm{x}$ \\
\end{tabular} & $\mathrm{x}$ & 29 & 85 \\
\hline 1.3 & Focusing on a new technology instead of the value process & $\mathrm{x}$ & & $\mathrm{x}$ & $\mathrm{x}$ & $\mathrm{x}$ & $\mathrm{x}$ & $\mathrm{x}$ & & $\mathrm{x}$ & $\mathrm{x}$ & & & & & & $\mathrm{x}$ & $\mathrm{x}$ & $\mathrm{x}$ & & & $\mathrm{x}$ & & $\mathrm{x} x \mid$ & $\mathrm{x}$ & $\mathrm{x}$ & $\mathrm{x}$ & & & $\mathrm{x}$ & & 18 & 53 \\
\hline 1.4 & Forgetting about employee working habits & $\mathrm{x}$ & $\mathrm{x}$ & $\mathrm{x}$ & & & $\mathrm{x}$ & & & & & & & $\mathrm{x}$ & $\mathrm{x}$ & $x$ & $\mathrm{x}$ & $\mathrm{x}$ & 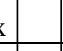 & & $\mathrm{x}$ & $\mathrm{x}$ & & & & & $\mathrm{x}$ & & $\mathrm{x}$ & & $\mathrm{x}$ & 14 & 41 \\
\hline 1.5 & Lack of understanding the implementation requirements & & $\mathrm{x}$ & $\mathrm{x}$ & $\mathrm{x}$ & $\mathrm{x}$ & $\mathrm{x}$ & $\mathrm{x}$ & & $\mathrm{x}$ & $\mathrm{x}$ & $\mathrm{x}$ & \begin{tabular}{l|l}
$x$ & $x$ \\
\end{tabular} & $\mathrm{x} x$ & $\mathrm{x} x$ & $\mathrm{x}$ & $\mathrm{x}$ & $\mathrm{x}$ & $\mathrm{x}$ & & $\mathrm{x}$ & $\mathrm{x}$ & & $\mathrm{x}$ & $\mathrm{x}$ & $\mathrm{x}$ & $\mathrm{x}$ & & $\mathrm{x}$ & \begin{tabular}{|l|l|l}
$\mathrm{x}$ & $\mathrm{x}$ \\
\end{tabular} & $\mathrm{x}$ & 26 & 76 \\
\hline 1.6 & $\begin{array}{l}\text { Conflict between traditional performance measures and value } \\
\text { reengineering goals }\end{array}$ & & $\mathrm{x}$ & & & $\mathrm{x}$ & & $\mathrm{x}$ & & & & & & $\mathrm{x}$ & $\mathrm{x}$ & $x$ & & & & & $\mathrm{x}$ & & & & & & $\mathrm{x}$ & & $\mathrm{x}$ & & $\mathrm{x}$ & 10 & 29 \\
\hline 1.7 & Not enough employee training to implement VRE & $\mathrm{x}$ & $\mathrm{x}$ & $\mathrm{x}$ & $\mathrm{x}$ & $\mathrm{x}$ & $\mathrm{x}$ & $\mathrm{x}$ & & $\mathrm{x}$ & $\mathrm{x}$ & $\begin{array}{ll}\mathrm{x} \\
\mathrm{x}\end{array}$ & \begin{tabular}{l|l}
$x$ & $x$ \\
\end{tabular} & \begin{tabular}{l|l}
$x$ & $x$ \\
\end{tabular} & \begin{tabular}{c|c}
$x$ & $x$ \\
\end{tabular} & $x$ & \begin{tabular}{l|l}
$x$ & $x$ \\
\end{tabular} & \begin{tabular}{l|l}
$x$ & $x$ \\
\end{tabular} & \begin{tabular}{l|l|} 
& $x$ \\
\end{tabular} & $x$ & $x$ & $\mathrm{x}$ & \begin{tabular}{l|l}
$x$ & $x$ \\
\end{tabular} & \begin{tabular}{c|c}
$x$ & $x$ \\
\end{tabular} & $\mathrm{x}$ & $\mathrm{x}$ & $\mathrm{x}$ & & $\mathrm{x}$ & \begin{tabular}{|l|l|}
$x$ & $x$ \\
\end{tabular} & $x$ & 31 & 91 \\
\hline 1b & Human related factors & $\theta$ & 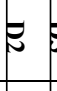 & $E$ & E & $\theta_{1}$ & 2 & & & 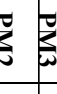 & & 8 & $\frac{5}{2}$ & $\frac{5}{6}$ & $\frac{5}{\infty}$ & $\frac{5}{6}$ & $\begin{array}{ll}b \\
B \\
B\end{array}$ & $\begin{array}{l}b \\
0\end{array}$ & E & $\beta_{i}$ & ह & $b_{0}$ & $\sum_{\infty}^{0}$ & \pm & $\underbrace{}_{2}$ & tit & 形 & 2 & स & $\lim _{0}$ & & Codes & $\mathbf{P}$ \\
\hline 1.8 & Workers' fear of job loss & $\mathrm{x}$ & $\mathrm{x}$ & $\mathrm{x}$ & & $\mathrm{x}$ & $\mathrm{x}$ & $\mathrm{x}$ & & & $\mathrm{x}$ & $\mathrm{x}$ & \begin{tabular}{l|l}
$\mathrm{x}$ & $\mathrm{x}$ \\
\end{tabular} & \begin{tabular}{l|l}
$x$ & $x$ \\
\end{tabular} & $\mathrm{x} x$ & $x$ & $\mathrm{x} \quad \mathrm{x}$ & \begin{tabular}{l|l}
$x$ & $x$ \\
\end{tabular} & 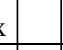 & $\mathrm{x}$ & $\mathrm{x}$ & $\mathrm{x}$ & $\mathrm{x} x$ & $\mathrm{x}$ & $\mathrm{x}$ & & \begin{tabular}{l|l}
$x$ & $x$ \\
\end{tabular} & $\mathrm{x}$ & $\mathrm{x}$ & \begin{tabular}{l|l}
$x$ & $x$ \\
\end{tabular} & $\mathrm{x}$ & 28 & 82 \\
\hline 1.9 & Uncertainty of project outcome & & $\mathrm{x}$ & & $\mathrm{x}$ & $\mathrm{x}$ & $\mathrm{x}$ & $\mathrm{x}$ & & $\mathrm{x}$ & $\mathrm{x}$ & & & $\mathrm{x}$ & & & $\mathrm{x}$ & $\mathrm{x}$ & $\mathrm{x}$ & & & $\mathrm{x}$ & & $\mathrm{x}$ & $\mathrm{x}$ & $\mathrm{x}$ & & & $\mathrm{x}$ & $\mathrm{x}$ & & 17 & 50 \\
\hline 1.10 & Sense of discomfort & $\mathrm{x}$ & $\mathrm{x}$ & $\mathrm{x}$ & & $\mathrm{x}$ & $\mathrm{x}$ & $\mathrm{x}$ & & $\mathrm{x}$ & $\mathrm{x}$ & & & $x$ & & & $\mathrm{x}$ & $\mathrm{x}$ & $x$ & & & $\mathrm{x}$ & & $\mathrm{x}$ & & $\mathrm{x}$ & & & $\mathrm{x}$ & & & 15 & 44 \\
\hline 1.11 & Anxiety in the workplace & $\mathrm{x}$ & $\mathrm{x}$ & $\mathrm{x}$ & $\mathrm{x}$ & $\mathrm{x}$ & $\mathrm{x}$ & $\mathrm{x}$ & & & & & $\mathrm{x}$ & & $\mathrm{x}$ & $x$ & $\mathrm{x}$ & $\mathrm{x}$ & $\mathrm{x}$ & & $\mathrm{x}$ & $\mathrm{x}$ & & & & & $\mathrm{x}$ & & & & $\mathrm{x}$ & 17 & 50 \\
\hline 1.12 & Collaborative work environment & $\mathrm{x}$ & $\mathrm{x}$ & $\mathrm{x}$ & $\mathrm{x}$ & $\mathrm{x}$ & & $\mathrm{x}$ & $\mathrm{x}$ & $\mathrm{x}$ & & $\mathrm{x}$ & & \begin{tabular}{l|l}
$x$ & $x$ \\
\end{tabular} & $x \quad x$ & $x$ & $\mathrm{x}$ & $\mathrm{x}$ & \begin{tabular}{l|l}
$x$ \\
$x$
\end{tabular} & & & $\mathrm{x}$ & & & & $\mathrm{x}$ & $\mathrm{x}$ & & & & & 19 & 56 \\
\hline 1.13 & Top management commitment & $\mathrm{x}$ & $\mathrm{x}$ & $\mathrm{x}$ & & $\mathrm{x}$ & & $\mathrm{x}$ & & $\mathrm{x}$ & $\mathrm{x}$ & & $\mathrm{x}$ & & & & $\mathrm{x}$ & $\mathrm{x}$ & 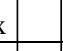 & & $\mathrm{x}$ & $\mathrm{x}$ & & $\mathrm{x}$ & $\mathrm{x}$ & $\mathrm{x} x$ & $\mathrm{x}$ & $\mathrm{x}$ & $\mathrm{x}$ & \begin{tabular}{l|l}
$x$ & $x$ \\
\end{tabular} & $\mathrm{x}$ & 20 & 59 \\
\hline 1.14 & Changes in the management system & $\mathrm{x}$ & $\mathrm{x}$ & $\mathrm{x}$ & $\mathrm{x}$ & $\mathrm{x}$ & & $\mathrm{x}$ & & & & & & $\mathrm{x}$ & $\mathrm{x}$ & $x$ & $\mathrm{x}$ & $\mathrm{x}$ & \begin{tabular}{|l|l}
$x$ & $x$ \\
\end{tabular} & & $\mathrm{x}$ & & & & $\mathrm{x}$ & & $\mathrm{x}$ & & & \begin{tabular}{|l|l}
$\mathrm{x}$ & $\mathrm{x}$ \\
\end{tabular} & $\mathrm{x}$ & 17 & 50 \\
\hline 1c & Process operational Factors & $E$ & $z$ & $z$ & E & $F_{\mu}$ & 2 & $\Rightarrow$ & 5 & $\begin{array}{l}0 \\
0 \\
2\end{array}$ & $\frac{1}{2}$ & $\frac{5}{\pi}$ & $\frac{5}{2}$ & $\frac{5}{3}$ & 5 & $\frac{5}{6}$ & $\sum_{2}$ & 象 & 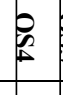 & b & b & $b_{\infty}$ & $0_{0}^{0}$ & \pm & 形 & 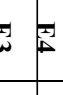 & 身 & $\mathrm{x}^{2}$ & $x_{3}$ & 70 & & Codes & $\mathbf{P}$ \\
\hline 1.15 & VRE was much larger than anticipated & $\mathrm{x}$ & & $\mathrm{x}$ & & & & & & $\mathrm{x}$ & & & & $\mathrm{x}$ & $\mathrm{x}$ & $x$ & $\mathrm{x}$ & $\mathrm{x}$ & $\mathrm{x}$ & & $\mathrm{x}$ & $\mathrm{x}$ & & & & $\mathrm{x}$ & $\mathrm{x}$ & & & & & 12 & 35 \\
\hline 1.16 & VRE was too disruptive to value operations & & & & $\mathrm{x}$ & & & & & $\mathrm{x}$ & & & & $\mathrm{x}$ & & & & & $\mathrm{x}$ & & $\mathrm{x}$ & & & & & $\mathrm{x}$ & & & & & & 6 & 18 \\
\hline 1.17 & Trying to change too much too quickly & & & & & & & & & & $\mathrm{x}$ & & $\mathrm{x}$ & & $\mathrm{x}$ & $x$ & & & & & & & & $\mathrm{x}$ & & & $\underline{x}$ & & $\mathrm{x}$ & & $\mathrm{x}$ & 8 & 24 \\
\hline 1.18 & Making value mistakes under pressure to produce quick result & & $\mathrm{x}$ & & $\mathrm{x}$ & $\mathrm{x}$ & $\mathrm{x}$ & $\mathrm{x}$ & $\mathrm{x}$ & & & $\mathrm{x}$ & & $\mathrm{x}$ & $\mathrm{x}$ & & & & $\mathrm{x}$ & & & & & & & & & & & & & 9 & 26 \\
\hline 1.19 & I ower employee productivity & & & & & & $\mathbf{x}$ & & & & & & & & & & $\mathrm{x}$ & $\mathrm{x}$ & 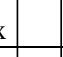 & & & $\mathrm{x}$ & & & $\mathrm{x}$ & $\mathrm{x}$ & & & & $\mathrm{x}$ & & 7 & 21 \\
\hline 1.20 & Lower employee morale & & & & $\mathrm{x}$ & & & & & $\mathrm{x}$ & & & $\mathrm{x}$ & & & & $\mathrm{x}$ & $\mathrm{x}$ & $\mathrm{x}$ & & & $\mathrm{x}$ & & & $\mathrm{x}$ & & $\underline{x}$ & & & \begin{tabular}{|l|l|l} 
& $x$ \\
\end{tabular} & $\underline{x}$ & 11 & 32 \\
\hline $1 \mathrm{~d}$ & Technical & i & & L & $\Delta$ & & p & $+x$ & & $0 \xi$ & 5 & $=5$ & 5 & $\bar{E}$ & $\sqrt{\pi}$ & $F$ & $\pm \vec{\infty}$ & 010 & $\approx$ & E & n & $E$ & $\begin{array}{l}E \\
\end{array}$ & $\approx F$ & 舟 & 0 & 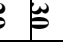 & 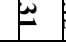 & 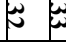 & \begin{tabular}{|l}
$\tilde{E}$ \\
\end{tabular} & & Total & $\%$ \\
\hline
\end{tabular}




\begin{tabular}{|l|l}
\hline 1.24 & Creating a new view of the organization \\
\hline 1.25 & Creating a shared process vision \\
\hline 1.26 & Management styles and leadership \\
\hline 1.27 & Encourage employees to learn \\
\hline 1.28 & Continuous growth and acceptance of change \\
\hline 1.29 & $\begin{array}{l}\text { Create conditions and opportunities to make organizational } \\
\text { change }\end{array}$ \\
\hline
\end{tabular}

change

1dii Client perspective

Client incorporation in the design phase so that the incidence of variations and time extensions are reduced.

1.31 Client requirement should be understood during brief

$1.31 \quad \begin{aligned} & \text { Client requirement should be } \\ & \text { development by the designer }\end{aligned}$

1.32 Involvement of Design team and client through partnering integration

1diii Appointment of contractors

\begin{tabular}{|l|l|}
\hline 1.33 & Past performance of the contractor \\
\hline 1.34 & Qualty sand of contor's wotk
\end{tabular}

\begin{tabular}{|l|l|}
\hline 1.34 & Quality standards of contractor's work \\
\hline
\end{tabular}

\begin{tabular}{|l|l|}
\hline 1.35 & Financial stability or status of the contractor \\
\hline
\end{tabular}

\section{\begin{tabular}{|c|c|}
\hline 1 div & Selection of contractual system \\
\hline 136 &
\end{tabular}}

\begin{tabular}{|l|l}
\hline 1.36 & Lump sum contract \\
\hline 1.37 & Design and constuct \\
\hline
\end{tabular}

\begin{tabular}{|l|l|l|}
\hline 1.36 & Lump sum contract \\
\hline 1.37 & Design and construct \\
\hline 1.38 & Turn- key contract \\
\hline 1.39 & Design and manage \\
\hline & 1.3 &
\end{tabular}

$1 \mathrm{dv}$ Risk sharing

$\sum$ ¿1.40 Risk issue relative to project participant

1.41 Risk strategy adopted by client

1 dvi

1.42 Existing common goal between the design team and client

1.43 Difficulties in design evaluation

1.44 Any formal approach to design evaluation

: 1.45 Core design parameters e.g Time, cost, Quality

1.46 Quality Function Development (QFD) facilitate evaluation of

$1.46 \quad$\begin{tabular}{l} 
proposed design \\
\hline
\end{tabular}

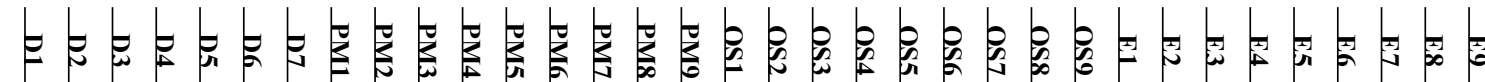

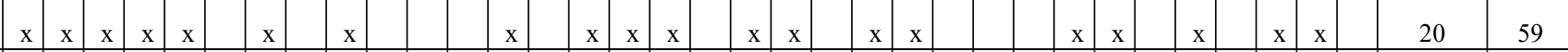

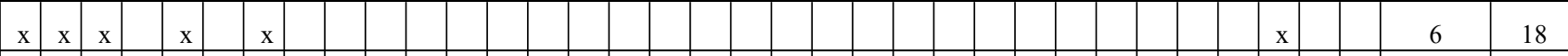

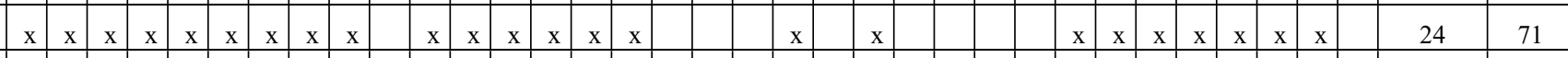

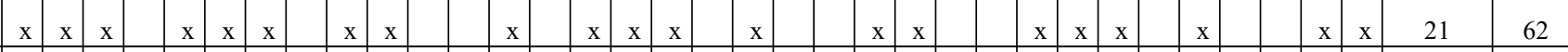

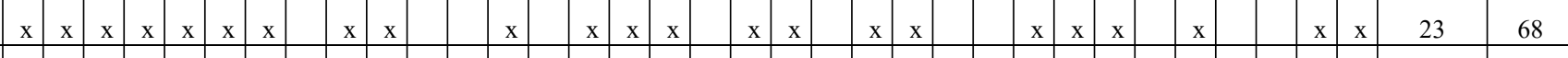

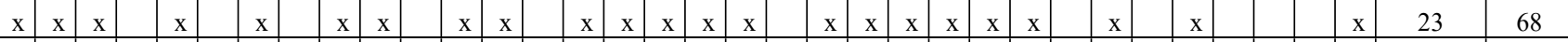

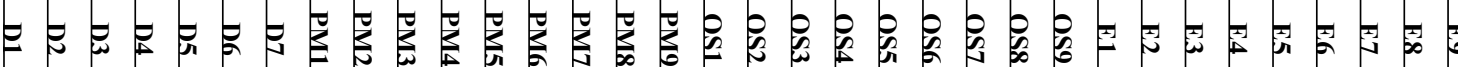

\begin{tabular}{l|l|l|l|l|l|l|l|l|l|l|llllllllllllllllllllllllllllllllll}
$\mathrm{x}$ & $\mathrm{x}$ & $\mathrm{x}$ & $\mathrm{x}$ & $\mathrm{x}$ & $\mathrm{x}$ & $\mathrm{x}$ & & $\mathrm{x}$ & $\mathrm{x}$ & & $\mathrm{x}$ & $\mathrm{x}$ & & $\mathrm{x}$ & $\mathrm{x}$ & $\mathrm{x}$ & $\mathrm{x}$ & $\mathrm{x}$ & $\mathrm{x}$ & $\mathrm{x}$ & $\mathrm{x}$ & $\mathrm{x}$ & $\mathrm{x}$ & $\mathrm{x}$ & $\mathrm{x}$ & $\mathrm{x}$ & $\mathrm{x}$ & $\mathrm{x}$ & $\mathrm{x}$ & $\mathrm{x}$ & $\mathrm{x}$ & $\mathrm{x}$ & & 30 & 59 \\
\hline
\end{tabular}

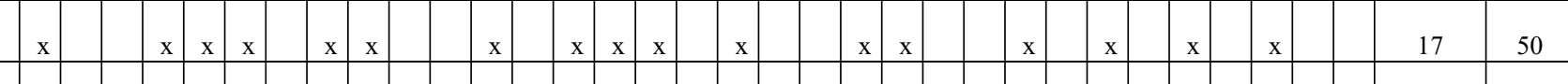

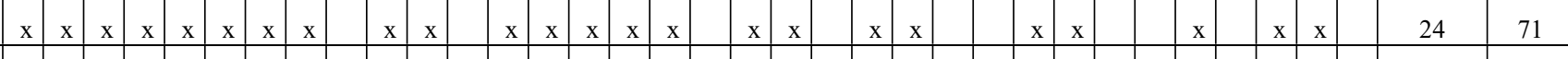

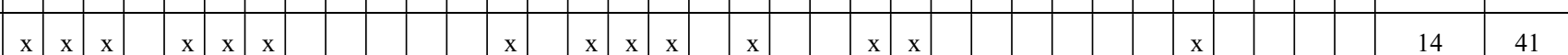

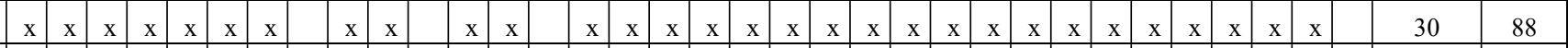

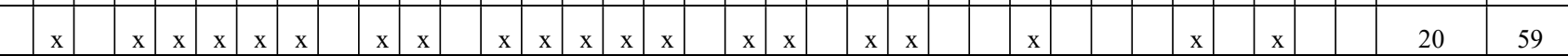

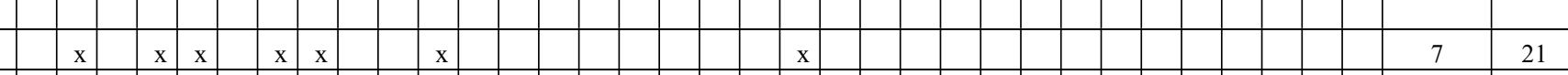

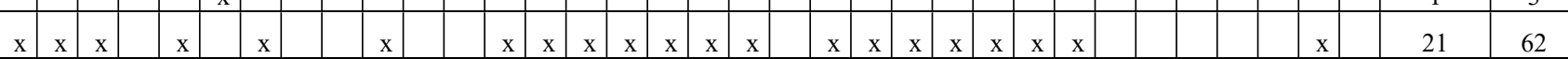

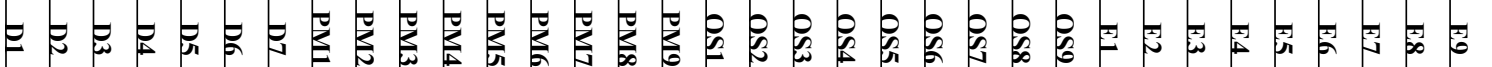
$\mathrm{x}$
$\mathrm{x}$

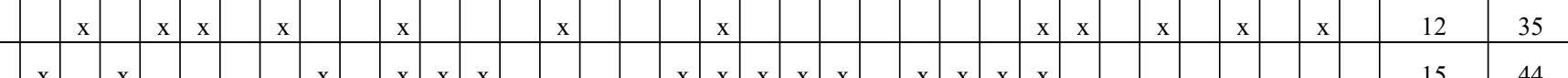
\begin{tabular}{|l|l|l|l|l|l|l|l|l|l|l|l|l|l|l|l|l|l|l|l|l|l|l|l|l|}
\hline & $\mathrm{x}$ & $\mathrm{x}$ & $\mathrm{x}$ & $\mathrm{x}$ & & & & & $\mathrm{x}$ & $\mathrm{x}$ & $\mathrm{x}$ & $\mathrm{x}$ & $\mathrm{x}$ & & $\mathrm{x}$ & $\mathrm{x}$ & $\mathrm{x}$ & $\mathrm{x}$ \\
\hline
\end{tabular}

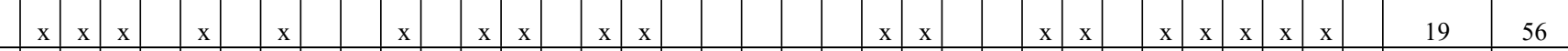




\begin{tabular}{|c|c|c|c|c|c|c|c|c|c|c|c|c|c|c|c|c|c|c|c|c|c|c|c|c|c|c|c|c|c|c|c|c|c|c|c|c|}
\hline $\begin{array}{l}1 \text { dvi } \\
\text { i }\end{array}$ & Constructability analysis & 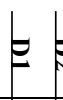 & & 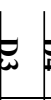 & & & & & & & & & & 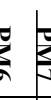 & & $\frac{1}{2}$ & & 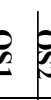 & & 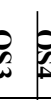 & & & 8 & $b$ & ? & & & & & X & th & S & $t_{\infty}$ & to & Codes & \\
\hline 1.47 & Allow review design by contractor to eliminate problem & $\mathrm{x}$ & $\mathrm{x}$ & $\mathrm{x}$ & & $\mathrm{x}$ & & $\mathrm{x}$ & & & $\mathrm{x}$ & & & $\mathrm{x}$ & & $\mathrm{x}$ & $\mathrm{x}$ & & & & & & $\mathrm{x}$ & & & & $\mathrm{x}$ & $\mathrm{x}$ & & & $\mathrm{x}$ & & $\mathrm{x}$ & & 14 & 41 \\
\hline 1.48 & Ease of construction & $\mathrm{x}$ & $\mathrm{x}$ & $\mathrm{x}$ & $\mathrm{x}$ & $\mathrm{x}$ & $\mathrm{x}$ & $\mathrm{x}$ & & & & & & $\mathrm{x}$ & & $\mathrm{x}$ & $\mathrm{x}$ & $\mathrm{x}$ & & $\mathrm{x}$ & $\mathrm{x}$ & & $\mathrm{x}$ & $\mathrm{x}$ & & & & & & & $x$ & & & & 16 & 47 \\
\hline 1.49 & Adoption of design features to site conditions & $\mathrm{x}$ & $\mathrm{x}$ & $\mathrm{x}$ & & $\mathrm{x}$ & $\mathrm{x}$ & $\mathrm{x}$ & & & $\mathrm{x}$ & & $\mathrm{x}$ & $\mathrm{x}$ & & $\mathrm{x}$ & $\mathrm{x}$ & $\mathrm{x}$ & & $\mathrm{x}$ & & & $\mathrm{x}$ & $\mathrm{x}$ & & & $\mathrm{x}$ & $\mathrm{x}$ & & $\mathrm{x}$ & $x \mid x$ & $\mathrm{x}$ & $\mathrm{x}$ & & 22 & 65 \\
\hline 1.50 & Enhancement of contractor's productivity & $\mathrm{x}$ & $\mathrm{x}$ & $\mathrm{x}$ & $\mathrm{x}$ & $\mathrm{x}$ & $\mathrm{x}$ & $\mathrm{x}$ & $\mathrm{x}$ & & $\mathrm{x}$ & $\mathrm{x}$ & $\mathrm{x}$ & $\mathrm{x}$ & $\mathrm{x}$ & $\mathrm{x}$ & $\mathrm{x}$ & $\mathrm{x}$ & & $\mathrm{x}$ & $\mathrm{x}$ & & $\mathrm{x}$ & $\mathrm{x}$ & & & $\mathrm{x}$ & & & & $x$ & $\mathrm{x}$ & & & 23 & 68 \\
\hline 1.51 & Ability to substitute materials, components and systems & $\mathrm{x}$ & & $\mathrm{x}$ & & & & & & & $\mathrm{x}$ & & & $\mathrm{x}$ & & $\mathrm{x}$ & $\mathrm{x}$ & $\mathrm{x}$ & & $\mathrm{x}$ & & $\mathrm{x}$ & $\mathrm{x}$ & $\mathrm{x}$ & & $\mathrm{x}$ & $\mathrm{x}$ & & & & $\mathrm{x}$ & $\mathrm{x}$ & & & 15 & 44 \\
\hline $\begin{array}{l}\text { 1dvi } \\
\text { ii }\end{array}$ & Project phase interaction & & & & & & & & & & & & & & & & & & & & & & & & & & & & & & & & & & & \\
\hline 1.52 & $\begin{array}{l}\text { Lack of interaction may affect quality and serviceability of design } \\
\text { phase }\end{array}$ & & $\mathrm{x}$ & & $\mathrm{x}$ & $\mathrm{x}$ & & $\mathrm{x}$ & $\mathrm{x}$ & & $\mathrm{x}$ & $\mathrm{x}$ & $\mathrm{x}$ & $\mathrm{x}$ & $\mathrm{x}$ & $\mathrm{x}$ & $\mathrm{x}$ & $\mathrm{x}$ & & $\mathrm{x}$ & $\mathrm{x}$ & & $\mathrm{x}$ & $\mathrm{x}$ & & & $\mathrm{x}$ & $\mathrm{x}$ & & $\mathrm{x}$ & $x$ & & & $\mathrm{x}$ & 22 & 65 \\
\hline 1.53 & Simultaneous consideration of conceptual design phase & $\mathrm{x}$ & $\mathrm{x}$ & $\mathrm{x}$ & $\mathrm{x}$ & $\mathrm{x}$ & $\mathrm{x}$ & $\mathrm{x}$ & & & $\mathrm{x}$ & & & & & & & $\mathrm{x}$ & & $\mathrm{x}$ & $\mathrm{x}$ & & & $\mathrm{x}$ & & & $\mathrm{x}$ & & & & $\mathrm{x}$ & $\mathrm{x}$ & $\mathrm{x}$ & $\mathrm{x}$ & 17 & 50 \\
\hline 1.54 & Concurrent design/construction are client satisfaction & $\mathrm{x}$ & $\mathrm{x}$ & $\mathrm{x}$ & & $\mathrm{x}$ & & $\mathrm{x}$ & & & $\mathrm{x}$ & & $\mathrm{x}$ & $\mathrm{x}$ & & $\mathrm{x}$ & $\mathrm{x}$ & $\mathrm{x}$ & & $\mathrm{x}$ & & $\mathrm{x}$ & $\mathrm{x}$ & $\mathrm{x}$ & & $\mathrm{x}$ & $\mathrm{x}$ & & & & $\mathrm{x}$ & $\mathrm{x}$ & & & 19 & 56 \\
\hline 1dix & Re-organizing work Packages & & & & & & & & & & & & & & & & & & & & & & & & & & & & & & & & & & & \\
\hline 1.55 & work packages by different contractors & & $\mathrm{x}$ & & $\mathrm{x}$ & $\mathrm{x}$ & $\mathrm{x}$ & $\mathrm{x}$ & $\mathrm{x}$ & & & $\mathrm{x}$ & $\mathrm{x}$ & & $\mathrm{x}$ & & & & & & $\mathrm{x}$ & & & & & & & $\mathrm{x}$ & & $\mathrm{x}$ & $\mathrm{x}$ & & $\mathrm{x}$ & & 14 & 41 \\
\hline $1 d x$ & Partnering with sub-contractors & & & & & & & & & & & & & & & & & & & & & & & & & & & & & & & & & & & \\
\hline 1.56 & $\begin{array}{l}\text { Partnering in the context of a contractor-sub contractor } \\
\text { relationship }\end{array}$ & $\mathrm{x}$ & $\mathrm{x}$ & $\mathrm{x}$ & $\mathrm{x}$ & $\mathrm{x}$ & $\mathrm{x}$ & $\mathrm{x}$ & $\mathrm{x}$ & & $\mathrm{x}$ & $\mathrm{x}$ & $\mathrm{x}$ & $\mathrm{x}$ & $\mathrm{x}$ & $\mathrm{x}$ & $\mathrm{x}$ & & & & $\mathrm{x}$ & $\mathrm{x}$ & $\mathrm{x}$ & & & $\mathrm{x}$ & $\mathrm{x}$ & $\mathrm{x}$ & & & $\mathrm{x}$ & $\mathrm{x}$ & $\mathrm{x}$ & & 24 & 71 \\
\hline $1 \mathrm{e}$ & Cost, Time and Information & 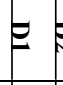 & z & $E$ & $E$ & & F & & & & & & & & 5 & $\int_{0}^{2}$ & & 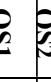 & & & 殿 & 贵 & 8 & $b_{0}^{0}$ & b & ? & 2 & & & 证 & 象 & P & $\$$ & to & Codes & $\mathbf{P}$ \\
\hline 1.57 & Top management reluctance to commit funds for VRE & & & & & & $\mathrm{x}$ & & & $\mathrm{x}$ & & & $\mathrm{x}$ & $\mathrm{x}$ & & $\mathrm{x}$ & $\mathrm{x}$ & $\mathrm{x}$ & & $\mathrm{x}$ & & $\mathrm{x}$ & $\mathrm{x}$ & $\mathrm{x}$ & & $\mathrm{x}$ & & & $\mathrm{x}$ & & $x$ & & & & 14 & 41 \\
\hline 1.58 & Time consuming & $\mathrm{x}$ & $\mathrm{x}$ & $\mathrm{x}$ & & $\mathrm{x}$ & $\mathrm{x}$ & $\mathrm{x}$ & & $\mathrm{x}$ & & & $\mathrm{x}$ & $\mathrm{x}$ & & $\mathrm{x}$ & $\mathrm{x}$ & $\mathrm{x}$ & & $\mathrm{x}$ & & $\mathrm{x}$ & $\mathrm{x}$ & $\mathrm{x}$ & & $\mathrm{x}$ & & $\mathrm{x}$ & $\mathrm{x}$ & $\mathrm{x}$ & $\mathrm{x} x$ & & $\mathrm{x}$ & & 23 & 68 \\
\hline 1.59 & Long implementation time rendered VRE changes obsolete & $\mathrm{x}$ & $\mathrm{x}$ & $\mathrm{x}$ & $\mathrm{x}$ & $\mathrm{x}$ & $\mathrm{x}$ & $\mathrm{x}$ & $\mathrm{x}$ & & & $\mathrm{x}$ & & $\mathrm{x}$ & $\mathrm{x}$ & $\mathrm{x}$ & $\mathrm{x}$ & $\mathrm{x}$ & & $\mathrm{x}$ & $\mathrm{x}$ & & $\mathrm{x}$ & $\mathrm{x}$ & & & & & & & $x$ & & & & 19 & 56 \\
\hline 1.60 & Rework time- variation and error & $\mathrm{x}$ & & $\mathrm{x}$ & & & $\mathrm{x}$ & & & & & & $\mathrm{x}$ & $\mathrm{x}$ & & $\mathrm{x}$ & $\mathrm{x}$ & & & & & & $\mathrm{x}$ & & & & & $\mathrm{x}$ & & & $x$ & $\mathrm{x}$ & $\mathrm{x}$ & & 12 & 35 \\
\hline 1.61 & material flow & $\mathrm{x}$ & & $\mathrm{x}$ & & & $\mathrm{x}$ & & & $\mathrm{x}$ & & & $\mathrm{x}$ & $\mathrm{x}$ & & $\mathrm{x}$ & $\mathrm{x}$ & & & & & $\mathrm{x}$ & $\mathrm{x}$ & & & & & & $\mathrm{x}$ & & $\mathrm{x}$ & & & & 12 & 35 \\
\hline 1.62 & $\begin{array}{l}\text { mode of information systems to support value reengineering } \\
\text { infrastructure }\end{array}$ & & & & & & & & & & $\mathrm{x}$ & & $\mathrm{x}$ & $\mathrm{x}$ & & $\mathrm{x}$ & $\mathrm{x}$ & & & & & & $\mathrm{x}$ & & & $\mathrm{x}$ & $\mathrm{x}$ & & $\mathrm{x}$ & & $x$ & & & $\mathrm{x}$ & 11 & 32 \\
\hline 1.63 & insufficient information & & & & $\mathrm{x}$ & & & & & $\mathrm{x}$ & $\mathrm{x}$ & & & & & & & & & $\mathrm{x}$ & $\mathrm{x}$ & & & & & & $\mathrm{x}$ & & $\mathrm{x}$ & & & & & & 7 & 21 \\
\hline 1.64 & $\begin{array}{l}\text { Lack of communication between CEO/top management and } \\
\text { Inspection officers/supervisory manager }\end{array}$ & & & & & & & & & $\mathrm{x}$ & & & $\mathrm{x}$ & $\mathrm{x}$ & & $\mathrm{x}$ & $\mathrm{x}$ & & & $\mathrm{x}$ & & & $\mathrm{x}$ & & & & & & & & $x$ & & & & 8 & 24 \\
\hline & Organizational Factor & 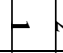 & & در & & & & & & 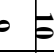 & & E & & A & $5 \pi$ & 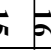 & & $\vec{x}$ & 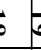 & 0 & 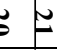 & $\sqrt{2}$ & ن & a & 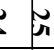 & $\approx$ & $\sqrt{4}$ & $\infty$ & $:$ & 空 & w & w & S & 車 & Total & $\%$ \\
\hline 1fi & Environment & $\underline{F}$ & $=$ & ב & $B$ & $\theta$ & z & z & & & & & & & 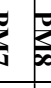 & & & 2 & & $p_{0}^{0}$ & 刍 & 要 & 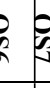 & $P_{0}^{0}$ & b & 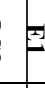 & $=$ & $x_{3}$ & $=$ & $=$ & 1 & $\mathrm{~A}$ & $x_{\infty}$ & to & Codes & \\
\hline 1.65 & Company environment not conducive to reengineering & $\mathrm{x}$ & & $\mathrm{x}$ & $\mathrm{x}$ & & & & & & $\mathrm{x}$ & & $\mathrm{x}$ & $\mathrm{x}$ & & $\mathrm{x}$ & $\mathrm{x}$ & & & & $\mathrm{x}$ & & $\mathrm{x}$ & & & & $\mathrm{x}$ & & & & $\mathrm{x}$ & $\mathrm{x}$ & & & 13 & 38 \\
\hline 1.66 & VRE created an unfriendly company environment & $\mathrm{x}$ & & $\mathrm{x}$ & & & & & & & $\mathrm{x}$ & & $\mathrm{x}$ & & & & & & & & & $\mathrm{x}$ & & & & $\mathrm{x}$ & $\mathrm{x}$ & & & & & $\mathrm{x}$ & & & 8 & 24 \\
\hline 1.67 & Downsizing but keeping the old organization structure & & & & & & & & & & & & & $\mathrm{x}$ & & $\mathrm{x}$ & $\mathrm{x}$ & $\mathrm{x}$ & $\mathrm{x}$ & $\mathrm{x}$ & & & $\mathrm{x}$ & $\mathrm{x}$ & & & & & & & $\mathrm{x}$ & & & & 9 & 26 \\
\hline 1.68 & Difficult implementation due to sub units communication barriers & & & & $\mathrm{x}$ & & & & & & & & $\mathrm{x}$ & & & & & $\mathrm{x}$ & & $\mathrm{x}$ & $\mathrm{x}$ & & & $\mathrm{x}$ & & & & & & & & & & & 6 & 17 \\
\hline 1.69 & Lack of leadership to face confrontations and major business risk & $\mathrm{x}$ & $\mathrm{x}$ & $\mathrm{x}$ & $\mathrm{x}$ & $\mathrm{x}$ & $\mathrm{x}$ & $\mathrm{x}$ & & $\mathrm{x}$ & $\mathrm{x}$ & $\mathrm{x}$ & $\mathrm{x}$ & $\mathrm{x}$ & $\mathrm{x}$ & $\mathrm{x}$ & $\mathrm{x}$ & $\mathrm{x}$ & $\mathrm{x}$ & $\mathrm{x}$ & $\mathrm{x}$ & & $\mathrm{x}$ & $\mathrm{x}$ & $\mathrm{x}$ & $\mathrm{x}$ & & $\mathrm{x}$ & & $\mathrm{x}$ & \begin{tabular}{l|l}
$x$ & $x$ \\
\end{tabular} & $x$ & $\mathrm{x}$ & & 25 & 73 \\
\hline
\end{tabular}




\begin{tabular}{|c|c|c|c|c|c|c|c|c|c|c|c|c|c|c|c|c|c|c|c|c|c|c|c|c|c|c|c|c|c|c|c|c|c|c|c|c|c|}
\hline 1.70 & Lack of senior management enthusiasm & & & & $\mathrm{x}$ & & $\mathrm{x}$ & & & & & & & $\mathrm{x}$ & & $\mathrm{x}$ & $\mathrm{x}$ & $\mathrm{x}$ & & $\mathrm{x}$ & $\mathrm{x}$ & $\mathrm{x}$ & $\mathrm{x}$ & $\mathrm{x}$ & & $\mathrm{x}$ & & & & & $\mathrm{x}$ & & & & & 13 & 8 \\
\hline 1.71 & Lack of employee consensus to see it through & $\mathrm{x}$ & & $\mathrm{x}$ & $\mathrm{x}$ & $\mathrm{x}$ & $\mathrm{x}$ & $\mathrm{x}$ & $\mathrm{x}$ & $\mathrm{x}$ & $\mathrm{x}$ & & $\mathrm{x}$ & $\mathrm{x}$ & $\mathrm{x}$ & $\mathrm{x}$ & $\mathrm{x}$ & $\mathrm{x}$ & $\mathrm{x}$ & $\mathrm{x}$ & & $\mathrm{x}$ & $\mathrm{x}$ & $\mathrm{x}$ & $\mathrm{x}$ & $\mathrm{x}$ & $\mathrm{x}$ & $\mathrm{x}$ & & & $\mathrm{x}$ & $\mathrm{x}$ & $\mathrm{x}$ & $\mathrm{x}$ & $\mathrm{x}$ & 29 & 85 \\
\hline 1.72 & $\begin{array}{l}\text { Lack of management determination to stay on course as problems } \\
\text { show }\end{array}$ & & & & $\mathrm{x}$ & & & & $\mathrm{x}$ & & & $\mathrm{x}$ & $\mathrm{x}$ & $\mathrm{x}$ & $\mathrm{x}$ & $\mathrm{x}$ & $\mathrm{x}$ & $\mathrm{x}$ & & $\mathrm{x}$ & $\mathrm{x}$ & & $\mathrm{x}$ & $\mathrm{x}$ & & $\mathrm{x}$ & & & & & $\mathrm{x}$ & & & & & 15 & 44 \\
\hline 1fii & Culture & $\xi$ & E & 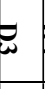 & 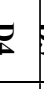 & $\beta_{n}$ & gू & $g^{\prime}$ & & $\frac{1}{3}$ & & & & & & & & & b & s & $b_{R}$ & 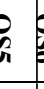 & & b & $b_{6}$ & p & $x^{2}$ & 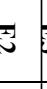 & $\mathrm{y}_{3}$ & $F$ & $\underbrace{\prime}_{1}$ & 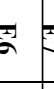 & 전 & X & to & Codes & \\
\hline 1.73 & subjective involvement with the work completion & $\mathrm{x}$ & $\mathrm{x}$ & $\mathrm{x}$ & & $\mathrm{x}$ & & $\mathrm{x}$ & & $\mathrm{x}$ & & $\mathrm{x}$ & & $\mathrm{x}$ & & $\mathrm{x}$ & $\mathrm{x}$ & & $\mathrm{x}$ & $\mathrm{x}$ & & $\mathrm{x}$ & $\mathrm{x}$ & $\mathrm{x}$ & $\mathrm{x}$ & $\mathrm{x}$ & & $\mathrm{x}$ & $\mathrm{x}$ & & $\mathrm{x}$ & & & $\mathrm{x}$ & $\mathrm{x}$ & 23 & 67 \\
\hline 1.74 & $\begin{array}{l}\text { Stability and behavior of staff originating from fundamental } \\
\text { values }\end{array}$ & $\mathrm{x}$ & $\mathrm{x}$ & $\mathrm{x}$ & $\mathrm{x}$ & $\mathrm{x}$ & $\mathrm{x}$ & $\mathrm{x}$ & $\mathrm{x}$ & $\mathrm{x}$ & $\mathrm{x}$ & & $\mathrm{x}$ & $\mathrm{x}$ & & $\mathrm{x}$ & $\mathrm{x}$ & $\mathrm{x}$ & $\mathrm{x}$ & $\mathrm{x}$ & $\mathrm{x}$ & & $\mathrm{x}$ & $\mathrm{x}$ & $\mathrm{x}$ & $\mathrm{x}$ & $\mathrm{x}$ & & $\mathrm{x}$ & & $\mathrm{x}$ & $\mathrm{x}$ & $\mathrm{x}$ & $\mathrm{x}$ & $\mathrm{x}$ & 29 & 85 \\
\hline 1.75 & Mindful of their mistakes by the customers & & $\mathrm{x}$ & & $\mathrm{x}$ & $\mathrm{x}$ & & & $\mathrm{x}$ & & $\mathrm{x}$ & & $\mathrm{x}$ & $\mathrm{x}$ & $\mathrm{x}$ & $\mathrm{x}$ & $\mathrm{x}$ & $\mathrm{x}$ & & $\mathrm{x}$ & & & $\mathrm{x}$ & $\mathrm{x}$ & & & & $\mathrm{x}$ & & $\mathrm{x}$ & $\mathrm{x}$ & $\mathrm{x}$ & & $\mathrm{x}$ & $\mathrm{x}$ & 20 & 58 \\
\hline 1.76 & Having the capacity and experience for change & $\mathrm{x}$ & $\mathrm{x}$ & $\mathrm{x}$ & $\mathrm{x}$ & $\mathrm{x}$ & $\mathrm{x}$ & $\mathrm{x}$ & $\mathrm{x}$ & $\mathrm{x}$ & $\mathrm{x}$ & $\mathrm{x}$ & $\mathrm{x}$ & $\mathrm{x}$ & $\mathrm{x}$ & $\mathrm{x}$ & $\mathrm{x}$ & $\mathrm{x}$ & & $\mathrm{x}$ & $\mathrm{x}$ & $\mathrm{x}$ & $\mathrm{x}$ & $\mathrm{x}$ & & $\mathrm{x}$ & $\mathrm{x}$ & $\mathrm{x}$ & $\mathrm{x}$ & $\mathrm{x}$ & $\mathrm{x}$ & $\mathrm{x}$ & $\mathrm{x}$ & $\mathrm{x}$ & $\mathrm{x}$ & 32 & 94 \\
\hline 1.77 & $\begin{array}{l}\text { Continually improving the organization's ability to value } \\
\text { customers }\end{array}$ & $\mathrm{x}$ & $\mathrm{x}$ & $\mathrm{x}$ & & $\mathrm{x}$ & $\mathrm{x}$ & $\mathrm{x}$ & & $\mathrm{x}$ & $\mathrm{x}$ & & & $\mathrm{x}$ & & $\mathrm{x}$ & $\mathrm{x}$ & $\mathrm{x}$ & $\mathrm{x}$ & $\mathrm{x}$ & $\mathrm{x}$ & & $\mathrm{x}$ & $\mathrm{x}$ & $\mathrm{x}$ & $\mathrm{x}$ & $\mathrm{x}$ & & $\mathrm{x}$ & $\mathrm{x}$ & $\mathrm{x}$ & $\mathrm{x}$ & $\mathrm{x}$ & $\mathrm{x}$ & $\mathrm{x}$ & 27 & 79 \\
\hline
\end{tabular}

